\title{
Industrial Dynamics and Endogenous Growth
}

\author{
Bo Carlsson \\ Case Western Reserve University, Cleveland, Ohio \\ and \\ Gunnar Eliasson \\ Royal Institute of Technology (KTH), Stockholm, Sweden
}

\begin{abstract}
Economic growth can be described at the macro level, but it can never be explained at that level. Economic growth is a matter of experimental creation of a variety of ideas, some of which result in new technologies that are confronted with potential buyers (customers) in dynamic markets and hierarchies. Thus, economic growth results from the interaction of a variety of actors who create and use technology and demanding customers. Economic growth is inherently a micro phenomenon. This process is not linear.

The focus of this paper is on the conditions that are conducive to creation of a variety of new ideas and on those that are necessary and sufficient for effective and efficient selection and retention of winners. We refer to the former as a technological system and the latter as a competence bloc, combined with an experimentally organized economy (EOE). The confrontation between actors and between actors and ideas gives rise to what we call industrial dynamics.

The paper is organized as follows. In sections 1, 2 and 3 we outline the main ideas behind the evolutionary theory of competence blocs and the experimentally organized economy (EOE) in which macroeconomic growth is generated by experimental selection. A dynamic version of Marshall's industrial districts is used as a pedagogical example to relate our thinking to both evolutionary economic modeling and to so-called New Growth theory. We then (section 4) summarize the concept of innovative technological supply or the technological system and (section 5) present the competence bloc as the organizer of a more or less efficient project selection process. In section 6 on industrial dynamics we explain how the confrontation between the creative innovators and economic actors who select projects yields economic growth. We illustrate the argument with a few case studies. In section 7, finally, micro-to-macro simulations of endogenous growth based on micro dynamics are presented.
\end{abstract}

Key words: Competence bloc theory, the experimentally organized economy, innovative behavior, technological system.

JEL code: $\mathrm{O} 14, \mathrm{O} 16, \mathrm{O} 31, \mathrm{O} 33$ 


\title{
Industrial Dynamics and Endogenous Growth
}

\author{
Bo Carlsson \\ Case Western Reserve University, Cleveland, Ohio \\ and \\ Gunnar Eliasson \\ Royal Institute of Technology (KTH), Stockholm, Sweden
}

\section{The Nature of Economic Growth - the Problem}

Economic growth can be described at the macro level but never explained at that level. Economic growth is basically a matter of experimental project creation and selection in dynamic markets and in hierarchies and of the capacity of the economic system to capture winners and remove losers. This is the nature of the Experimentally Organized Economy (EOE). Expressed differently, economic growth is essentially a matter of the decentralized endogenous allocation of human or team-embodied competence in the economy. This requires that each project gets exposed to a maximum of competent evaluation so that (1) potential winners will experience increasing economies to continued search and (2) a selection of winners together making up a positive sum game is created (G. Eliasson and A. Eliasson 1996, Eliasson 1996,1998c, 2000a, b, 2001a, Eliasson and Taymaz 2000). Competence bloc theory within the EOE explains the nature of the selection. The mass of human embodied competence and the principles of its allocation on tasks represent a competence memory of the economy that has to be understood to comprehend economic growth.

Technology and competence are universally acknowledged to be positive growthpromoting capital inputs in production. However, the concepts of technology and competence are not well defined and cannot be well defined since their multidimensional character makes their definition dependent on their allocation, or purpose (Eliasson 2000c, 2001a). For them to be concretely represented in testable theory, a different approach is needed. The technological system (Carlsson and Stankiewicz 1991, Carlsson 1995 and 1997) aims at giving technology and technical competence and the conditions favorable to their creation a concrete representation in economic theory. Competence bloc theory explains the allocation of the same competences on tasks valued from the demand/customer side. We have, so to speak a dynamic demand and supply situation where demand and supply, making standard Walrasian demand and supply analysis utterly meaningless. However, other factors, notably institutional 
ones, are also at work in the economy, exercising the same positive influences. The effects of new technology and competence on economic growth may be conditional on the existence of several critical institutional circumstances, which makes it scientifically incorrect to build and test models of economic growth in which technology exercises a direct ("linear") positive leverage on output by prior design. New technology introduced through entry may, in fact, be wholly contingent upon a number of institutional factors, notably access to competent venture capital, and above all (see section 7), upon the existence of a viable exit mechanism (Eliasson and Taymaz 2000). The correct specification is highly non-linear and closer to the Austrian Schumpeter (1911) than his later linearized (1942) version. Competence bloc theory (G.

Eliasson and $\AA$. Eliasson 1996, Eliasson 1997a) and technological systems together create the non-linear micro-based systems dynamics that explain economic growth. But such industrial dynamics (a positive sum game) are by definition and design excluded both from the neoclassical model and from recent linear versions of evolutionary Schumpeterian modeling. The experimentally organized economy and the embodied theory of competence blocs, however, grow from experimental selection in markets and hierarchies. We therefore have to be precise in defining our departure from the linear Schumpeterian model and from the neoclassical model or the Walras-Arrow-Debreu (WAD) paradigm into non-linear experimental country. This can be done by beginning with Alfred Marshall who struggled already in 1890 with the problems WAD theory and I/O theory have yet to solve.

\section{Marshall on New Growth Theory}

Adam Smith (1776) summed up his observations on the industrial reorganization process that was taking place around him by referring to decentralization of production (outsourcing), economies of scale and coordination through markets (the invisible hand) as the determinants of the growth of the economic wealth of nations. Adam Smith's theory constituted an open-ended system (Loasby 1991) with an "infinite state space." He was satisfied with having a dynamically coordinated and growing (value creating) economy and hence made no distinction between equilibrium and stability (Eliasson 1983, 1992). Smith had no need for static equilibrium. Walras (1772) closed the system by imposing market clearing. This was a remarkable intellectual achievement in itself, but it removed economic theory from a previously solid empirical footing. It also created "new" theoretical problems, 
above all how to handle the increasing returns everywhere visible, when theory demanded decreasing returns in order for an interior equilibrium to be reached.

Marshall $(1890,1919)$ was frustrated by that incompatibility between facts and theory. His solution was to create the concept of a positive externality in the form of an industrial district (Eliasson 2001a). Individual firms experienced decreasing returns when increasing one input, ceteris paribus. But the decreasing returns effect could be overcome by joining an industrial district and there enjoy a positive systems (synergy) effect, a positive externality. This positive systems effect from the industrial district is closely related to the notion of technological spillovers (Eliasson 1997a).

Marshall's endeavors were not appreciated by his contemporaries, especially when he continued insisting in Industry and Trade (1919) that economic theory had a problem with reality. Sraffa (1926) attempted to argue the problem away. Young (1928) agreed, saying essentially that Walrasian theory was useless when it came to explaining and understanding dynamics. Hicks (1939) looked down from his academic pinnacle and simply stated that such heresy was not to be allowed (for a survey see Laestadius 1999).

In Marshall's view, output at each point in time was limited from above by the invisible competence or systems capital of the entire industrial district, a knowledge capital that could only be raised slowly, and at rapidly decreasing returns (Eliasson 1989, in Carlsson 1989) to investments in building such systems knowledge capital. In today's language this could be seen as an early theory of spillovers (Eliasson 1997a, in Carlsson 1997) or a modern microbased version of (now old) new growth theory. Romer (1986) used exactly the same idea in his macro new growth model (bu without citing Marshall) when he introduced a systems competence capital, an externality in a traditional neoclassical growth model. Also, in Romer (1986, 1987, 1990) and in Lucas (1988) an interior static equilibrium was achieved by postulating rapidly diminishing returns to learning or accumulating the externality.

The world of the EOE is more in the tradition of Marshall than that of the static macro world of new growth theory. New growth theory can be seen as a statistical measurement design of our model and of Marshall's model, in the sense that data being generated by a model of the EOE would also be compatible with a macroeconometric model of new growth theory. The explanation of the same growth data would, however, be entirely different (see below). Only the EOE is based on Schumpeterian dynamics in the way he saw it himself through his then (1911) Austrian eyes. But in order to capture the dynamics, we need to 
specify both the demand side (the selection process) and the supply side, where and how new ideas and technologies are created, and the confrontation of the two dimensions.

\section{The Dynamics of the Experimentally Organized Economy}

The experimentally organized economy rests on the assumption of an enormous state space (set of technical possibilities) that (1) is completely non-transparent to all actors in the model economy including central Government, (2) includes business solutions that are far superior to all known business solutions (Eliasson 1998a, 2001a), and (3) features a set of business opportunities that is constantly expanding through learning or search into it, and (4) constantly leads to business mistakes. Here we talk about the Särimner effect, recognizing the pig from the Viking sagas that was eaten for supper, only to return next afternoon, to be eaten again for supper (Eliasson 1987, 1992). The only difference is that the business opportunity set expands from being exploited. We have a positive sum game. The expansion of the business opportunity set is supported by innovations from the technological systems.

The assumptions of the vast and completely non-transparent opportunity set sets the theory of the EOE apart from the neoclassical or Walras-Arrow-Debreu (WAD) model (Eliasson 1992). The WAD model state space is small and fully transparent by assumption. Agents make no business mistakes by assumption. Even the central planner can do his job without making an error, by assumption. But when the technical possibility set is virtually unlimited, the identification of technical possibilities and their conversion into business opportunities is beyond explicit human analytical faculties. Once technical possibilities are identified, they can form the core of a technological system. This requires an organization of knowledge as well as of human beings, or groups of human beings with embodied (tacit) competences. The identification and exploitation of business opportunities arising from these technical possibilities is done within what we call a competence bloc. As individuals or organizations they will be making business mistakes, and that holds for the government as well. But they will all learn, create competence and use competence. How that competence is created and allocated needs to be incorporated into the analysis. The only thing we know for sure is that, however well all actors do their jobs, there will always be better but unknown ways to do the same job.

To formulate the theoretical framework, we consequently have to break up the very foundation of the neoclassical model. We then arrive at the model of the EOE in which actors 
are compelled by each other to act in order not to succumb to competition, and in which growth occurs through experimental project selection. There competence bloc theory is needed to understand the nature of that selection. Very little change, indeed, is needed to leave the WAD model and arrive in the EOE world.

\section{The Knowledge-Based Information Economy}

We first introduce the notion of a knowledge-based information economy where extreme quality variation characterizes demand (Eliasson 1990b, 1996). This allows us to establish the empirical foundation for a state space (of our model) of such enormous dimensions that (almost) all actors become grossly ignorant even of (for them) relevant circumstances. This change in assumptions for our analysis is basic in that it removes the theoretical possibility of both optimizing and maintaining the assumption that ex ante plans equal ex post outcomes (Eliasson 1992). The empirical relevance of the change in assumptions is documented by demonstrating that the use of resources for information processing and communications by producers "to find an equilibrium" (assumed to be zero in the WAD model or approximately so in most I/O models) dominates resource use in the normal business firm (Eliasson 1984b, 1989, 1990a, b). This means that business decisions will have to be seen as more or less well prepared (business) experiments that often fail. There will be no such thing as an external equilibrium to look for. We are in the model of the EOE, where growth occurs through experimental selection.

\section{The Experimentally Organized Economy}

The theory of the EOE is an alternative to the Walras-Arrow-Debreu model (Eliasson 1992). The main difference between the two is the assumed size of state space. It is assumed to be extremely small and sufficiently transparent for actors to identify all options in the WAD model. It is extremely large and non-transparent in the EOE. The EOE thus embodies the experimental nature of a viable market economy. It has its roots in the Austrian economics of Carl Menger (1871) and further elaborations of Schumpeter (1911), but before he "became linearized" (1942). The EOE features economic growth through experimental creation and selection of innovative projects in markets. The policy makers in the EOE constantly face the problem of efficient exit, i.e., forcing badly managed incumbents or new losers to exit without 
also forcing winners to exit. This is a typical (dynamic) efficiency problem. In stylized form we can talk about the Schumpeterian creative destruction process as it is presented in Table 1.

(Table 1 in about here)

The following analysis allows us to "derive" the growth model in Table 1. The performance characteristics of an agent (e.g., in terms of profitability or productivity) can be ranked in each market as in the Salter curves of Figure 1. Superior firms to the left can beat lower down firms in hiring people, buying components, lowering prices or acquiring firms. The challenged firms know this and have to act to improve their situation, thus challenging the (temporarily) superior firm. All incumbents are challenged by new entrants, and challenged firms that cannot cope with the situation are forced down the curve, eventually to exit at the lower right hand corner. Competition is endogenous, forcing organizational innovative behavior as represented by the four categories of Table 1 of Schumpeterian Creative Destruction (see further Eliasson 1996, p. 45, 1998a, 2001a).

If society is "efficiently" organized and equipped with the right institutions and incentives, this dynamically competitive process of experimental selection will lead to macroeconomic growth through the outward shifting of the Salter curves. But the built-in (endogenous) competition could also lead to contraction and exit. The problem for the policy maker is to organize institutions such that winners are retained and losers forced to release resources, notably labor, to the growing firms. This dynamic turns exiting losers into growth promoting factors (Eliasson, Johansson and Taymaz 2001). Hence, the efficiency of the selection becomes important.

Dynamic efficiency in the EOE can be characterized by the capacity of the economic system to minimize the economic consequences of two types of errors; not to keep losers for too long and (most important) not to lose the winners (see Table 2A).

The solution is a matter of organizing diverse and distributed competences in the economy such that each project is exposed to a maximum of competent and varied evaluation. We use competence bloc theory to analyze this situation (G. Eliasson and $\AA$. Eliasson 1996). Before we get there we have to look at the nature of the supply of innovations to be filtered through the competence bloc, i.e., at the markets for innovation.

(Tables $2 \mathrm{~A}$ and $\mathrm{B}$ in about here). 


\section{The Supply of Innovations - the Technological System}

Technology constitutes the core of a technological system. Whereas a competence bloc is defined in terms of its output, technological systems are defined in terms of technology. Technological systems are the systems frameworks that support the supply of innovations.

There are three dimensions to technological systems: (1) a cognitive dimension defining the clustering of technologies resulting in a new set of technological possibilities, (2) an organizational and institutional dimension capturing the interactions in the network of actors engaged in the creation of these technologies, and (3) an economic dimension consisting of the set of actors who convert technological possibilities into business opportunities.

\section{Design Space - the Cognitive Dimension of Technological Systems}

The concept of "technology" is notoriously ambiguous. The term connotes the sum total of intellectual resources necessary for the production and distribution of goods and services. Technology is knowledge, but it is distinctly different from other forms of knowledge, such as science. As a cognitive system, technology has a structure, albeit one that continues to be poorly understood.

Technology can be interpreted as a set of combinatorial design spaces formed by clusters of complementary technical capabilities (Stankiewicz 2001). Design spaces undergo constant evolution. We can distinguish between three modes of technological growth (accumulation) in the design spaces.

- The expansion of the space through the addition of new capabilities or clusters of capabilities (as is the case in technological fusion);

- The progressive integration and structuring of the design spaces through the co-evolution of its various elements;

- The accumulation of application-specific know-how linked to the evolutionary trajectories of particular artifacts, such as, for instance, aircraft.

Our definition of technology highlights the combinatorial character of innovation. Of course, the emergence of new technological clusters or the transformation of existing ones can 
be initiated by a particular technical break-through. Thus, in the case of "new" biotechnology, the triggering events were Watson and Crick's discovery of the double helix or the DNA structure and how it is used in the cells and the consequent development of a series of techniques around the mid-1970s, such as recombinant DNA and monoclonal antibody techniques (Eliasson, ^. 2001). However, the growth and expansion of a design space and, with it, of the technological opportunity set, usually requires that such novelties be integrated within a wider cluster of competencies. Thus, biotech is merging with laboratory technology, computer technology, agricultural practices (Eliasson, A., 2001), as well as health care (Eliasson, G., 2001c) in a variety of new combinations. Hence, the boundaries and characteristics of technological systems originate in various design spaces that grow, mature, subdivide and/or converge. As a result, new technological possibilities emerge, some of which constitute business opportunities. The current explosion of business opportunities in the computing and communications industry can be explained by the special enabling features of digital technology (Eliasson 1980, 1996), a subset of which constitutes computing and communications technology. But before we explore the dynamics of the formation of technological systems we need to consider the organizational dimensions of the system.

\section{The Organizational and Institutional Dimension}

A second dimension of a technological system is the network of actors who embody the system. It consists of all individuals who contribute to the growth and structuring of the design space in question. These individuals are spread across a variety of organizations: companies, universities, other R\&D and educational organizations, public bureaucracies, industry organizations, and so forth. They include inventors, researchers, engineers, managers and bureaucrats, proselytizers and critics, and many others. Such technological communities support the formation of problem-solving networks, and, hence, also innovation. As the design space changes (and with it the supporting knowledge base), the relevant actors and networks also change.

These technological communities provide the basic social matrix that encourages or discourages the formation of effective problem-solving networks. Their members are linked by a variety of relationships including shared organizational affiliation, professional links, buyer-supplier relationships, social ties, etc. These linkages determine the R\&D agendas of different actors and the patterns of communication, collaboration and competition among them. Their strength and density depend on the geographic location of the actors, their 
institutional affiliation, the economic incentive regimes under which they operate, cultural factors, and so forth. They can be influenced by various deliberate policies such as the creation of appropriate bridging institutions, employment policies, or communication policies. Indeed, one of the main aims of technology policy is to promote the growth and interactivity within these actor networks.

The properties of the actor networks forming technological communities are closely correlated with the properties of the design spaces. As technical knowledge grows and the design spaces evolve, the processes of problem solving, knowledge creation, information storage and transfer all undergo changes that often require new organizational and institutional forms. Particularly important are those changes which redefine the boundaries of the design space. They may be brought about by radical advances in a particular region of a single design space or by the "fusion" of two separately evolved design spaces. In either case they call for the formation of new actor networks and organizations.

\section{The Economic Dimension}

There is a third dimension of technological systems - the actors who convert technical possibilities into business opportunities. Each set of technical possibilities can give rise to a variety of business opportunities. Each set of business opportunities can be exploited in a different market. Thus, to the extent that a generic technology (such as biotechnology) which forms the core of a technological system creates business opportunities in several markets (e.g., biomedicine and agriculture), it may be associated with economic actors in several different arenas. We refer to the economic actors in a particular arena (such as health care services) as a competence bloc.

The primary function of a technological system is to organize technical knowledge and the actors who embody this knowledge, as well as organizations and institutions supporting the creation and diffusion of knowledge, in such a way as to promote the conversion of technical possibilities into business opportunities. The effectiveness and efficiency of this conversion process depends on the economic actors in the competence bloc or blocs associated with the technology.

The technological system is based on the early notion of "development blocs" (Dahmén, 1950, 1989, Carlsson and Henriksson 1991). Development blocs are created by 
emerging resource complementarities which give rise to structural tensions in an economic system - at national or regional level. Effective innovation and economic growth depend on the ability of economic actors to resolve these tensions by exploiting the complementarities through entrepreneurial action. The end result is a development bloc of mutually reinforcing economic activities.

\section{Selection in the Market: Competence Bloc Theory}

In the vast and non-transparent business opportunity set of the EOE, even very competent actors are grossly ignorant of for them relevant circumstances, not only of the supplies of radically new innovations (the technological system) but also of the competence and strategic actions of competitors. Business mistakes become a normal outcome of the experimental selection process, and the efficiency of that selection becomes a core problem both for the firm and for the economy at large.

Competence bloc theory deals with that efficiency problem. It is defined by the (minimum) set of functions, performed by actors with competence needed to minimize the negative economic consequences of the two kinds of business mistakes in Table 1A. The EOE recognizes tacit competencies. The competence bloc is a theoretical design that allows us to deal with the efficient organization of decentralized tacit knowledge without specifying the content of knowledge except by function and to some extent by carrier. One could, therefore, say that a competence bloc also defines the minimum set of actors needed to develop an industry.

At this stage of our presentation two actors dominate the scene: the customer and the innovator. The customer represents the demand side and is the ultimate arbitrageur in $a$ market economy. The innovator represents the supply side of new technology. Industrial dynamics occurs when the two meet directly or through their representative intermediaries in the markets.

We have, at the top of the list (item 1; Table 2B), the competent customer who defines the maximum degree of "sophistication" of the project for which the most advanced customers

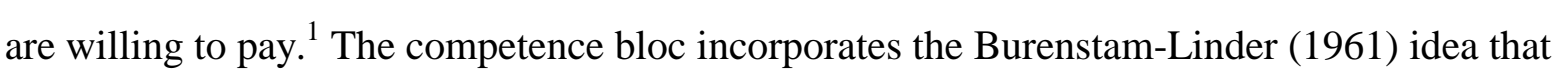
advanced customers constitute a comparative advantage for the rich industrial countries. The

1 It should be noted that the customer here is assumed to know what the desired product is and what its desirable features are. 
customer often contributes directly to product technology in the purchasing of advanced products such as aircraft, where the user may be as technologically knowledgeable as the producer. The normal situation, however, is that the customer chooses between different product offers. Heterogeneity in the supply of innovative new products and a rich supply of competent customers with varying tastes, therefore, is important for technological advance.

The innovator (item 2) is defined to be the actor who combines new and old technologies into new composite technologies ${ }^{\mathrm{Q}}$, to be selected by economic (profitability) criteria by the entrepreneurs (item 3). As mentioned already, innovative technology supply in item 2 establishes contact with the technological system of the previous section. The innovator should be defined in theory as a technologically competent actor, even though he/she in practice may act also in the capacity of an inventor and an entrepreneur. The dynamics of the markets for innovation are to be found in the intersection of the technological system and the innovation item in Table $2 \mathrm{~B}$. This intersection with the competence bloc is the focus of the analysis of the next section.

The entrepreneur, in turn, normally needs external financing to move expected winners on, and that financing has to be associated with the competence needed to understand the entrepreneurial selection. Otherwise the conditions will be so tough as to leave little or nothing for the innovator and the entrepreneur (G. Eliasson and Å. Eliasson 1996, Eliasson 1997b). The competent venture capitalist (item 4) selects the winning entrepreneurs. The venture capitalist, however, needs a large and viable exit market (item 5) to unload his stake profitably, at an appropriate time. If a real winner is moving through the competence bloc, the next step is for a competent industrialist (item 6) to take over and move the project on to industrial scale production and distribution. Apparently, all later stages (actors in the competence bloc) are important for establishing the incentives to act at earlier stages. If the competence bloc is not vertically complete, the risks are large that even winners will "get lost".

But vertical completeness is not sufficient (Eliasson 2001a). One actor of each does not guarantee a varied and competent project evaluation. Many of each with greatly different competences are needed. Only when vertical completeness and horizontal variety are in place

2 This is the definition of Mises (1949), We prefer that to the more unclear definition of Schumpeter, who allowed our innovators and entrepreneurs to mix. We want the term to apply to the task or function. Our definition is therefore the appropriate one in a theoretical context, even though the innovator and the entrepreneur in reality may be one and the same person. 
can potential winners confidently pursue their search. Increasing returns to continued search then prevail and the risks that winners may get lost are minimized.

Thus, competence bloc theory is sufficient to demonstrate not only the critical role played by competent venture capitalists and exit markets to identify and move winners in new technologies to industrial scale production. It also demonstrates the need for variety or heterogeneity (Eliasson 1984).

A large company internalizes more or less the various functions of the competence bloc, notably venture financing, the exit markets and the industrialization process. It does that by reducing variety in the selection process, because innovative variety disturbs the static efficiency of a large hierarchy (Eliasson 1976). The distribution of internal firm activities over a competence bloc therefore offers an organizational solution by combining the innovative creativity of the small entrepreneurial firm with the static efficiency of the large volume producer (G. Eliasson and Å. Eliasson, 2000).

\section{Innovative Supply}

The nature of innovative supply, notably of radically new innovations, has been the subject of both scholarly study and intellectual controversy. Some would argue (as did Schumpeter 1911) that innovations are by definition beyond analytical understanding. They enter the stage of economic activity as an unpredictable deus ex machina. This is the basic notion of our analysis. However, once a technical possibility has been identified, technological systems and competence blocs are designed to be helpful tools in analyzing how that technical possibility is converted into business opportunities and economic growth. The greater the receiver competence (Eliasson 1986, 1990a) or absorptive capacity (Cohen and Levinthal 1990) in the system, the greater is the chance that opportunities will be identified.

Later, when he was established in the U.S. academic world, Schumpeter (1942) modified his view on innovative activity, allowing for a one-to-one linear (sequential) relationship between $R \& D$ investments and innovative output. This opened the door for Schumpeterian R\&D-based innovation production functions, which brought Schumpeterian analysis uncomfortably close to neoclassical production-function based "growth theory." Mainstream economists have seized this opportunity to build so called neo-Schumpeterian, almost neoclassical innovation supply models. New growth theory belongs here and it is in many respects close to the innovation systems approaches. 
By placing the technological system in the model of the Experimentally Organized Economy (EOE) we break the sequential approach. It means, in fact, that we are taking the Nelson - Winter (1982) evolutionary model back into the original Darwinian environment of Winter (1964).

For the purpose of this essay it is sufficient to look at the creation of radically new innovations as a more or less random creation of "mutations" (as in Winter 1964, or Winter 1986) or a similar process supported by genetic learning mechanisms as in Ballot and Taymaz (1998).

The dynamics of the EOE, hence, represents a theory of micro based endogenous growth. The same process of economic growth is also represented on stylized form in the Swedish micro-to-macro model or the MOSES model economy. The generalized Salter (1960) curve dynamics of the Moses model economy (Eliasson 1991a) makes it possible to present EOE dynamics in quite concrete language and explicitly relate it to macroeconomic growth (see further section 7).

\section{Industrial Dynamics and the Markets for Innovation}

The defining characteristic of the technological system is the technology at its core; this technology may change over time as the underlying design space shifts. Thus, the technological system views the innovation process primarily from the (technology) supply side. The core technology may be manifested in a variety of products. For example, biotechnology is applied in pharmaceuticals as well as in agriculture, food industry, and possibly many other industries, including the forest industry. Each of these industries uses biotechnology as one among several technology inputs. For example, the pharmaceutical industry uses technologies originating in other knowledge areas, e.g., chemistry, chemical engineering, and mechanical engineering, in addition to biotechnology. Thus, there is not necessarily any one-to-one correspondence between a technology and a particular product or product area. Indeed, the application of a technology may not at all be in the area originally envisioned by the innovator but in an entirely different area instead.

If we view the innovation process from the demand or product (competence bloc) side instead, we may find that the end product (say, delivery of health care services) is made up of a whole range of components, each dependent on a different technology or set of technologies 
(and supporting technological systems). Diagnostic instruments, pharmaceuticals, and medical supplies are examples of such components in the delivery of health care services.

This means that at any moment there is competition among technologies in each product area. A knowledge breakthrough may shift the design space for a particular technology and lead to a reconfiguration of the product range based on that technology (new products entering and others exiting). Whether or not this leads to a different menu of products being offered in the market depends on the next step in the innovation process. Innovators may now enter the process, combining and integrating the new technologies in various ways, each perhaps identifying different potential markets and customers. The same idea may have potential application in several product areas simultaneously - or none at all.

This is where the supply and demand sides meet, if indeed they meet at all. Before a product is offered in the market, it must be identified as a potential winner. This is the role of the entrepreneur who must also find the resources (management, finance, etc.) necessary successfully to commercialize the product.

Thus, there is selection going on both within and among technologies and the supporting technological systems. Innovators select and combine technologies into products. The result of this selection process is a potentially marketable product or set of products. Then the market selection takes place within the competence bloc, one for each product market. The technological system and the competence bloc overlap in that they have some actors in common. The interface is where an innovator finds a potential application of a technology (a product) and is identified as a potential winner.

The technological system supplies a variety of innovative technologies to be subjected to the entrepreneurial selection process in the competence bloc and guided over financial market by customer (demand) signals. In the intersection of the technological system (item 2 in Table 2B) and the entrepreneurial selection process (item 3) a market for innovations is established that selects winners to be moved on through the competence bloc to industrial scale production and distribution.

Many, perhaps most innovators do not fare well in this sorting but are forced to exit at an early stage. Others fare better, but their fate depends on their business plans being accepted and understood by the financial actors and - if winners - moved on by industrialists who have the receiver competence (Eliasson 1986, 1990a, Cohen and Levinthal 1990) to efficiently convert them into volume production and distribution. This last function also often fails due to deficient (receiver) competence. (For example see Eliasson 1980, 2000c). 
The competence applied to individual projects during this filtering determines whether winners are selected and moved on and losers forced to exit. But competence is only a necessary, not a sufficient requirement. Incentives have to be in place to make winners willing to invest and grow and competition to force them to do so and push losers down and out. This is a matter of the existence of the right institutions.

\section{The Role of Institutions}

The important role of institutions of the EOE is to convert the creative destruction process of Table 1 into a positive sum game of growth. This is partly a matter of positive selection of winners, the allocation of resources on winners, and the withdrawal of resources from losers such that they stop growing and /or exit (necessary conditions). It is also a matter of the existence of incentives and competition that create and orient economic actors in their search for profit (Eliasson 2001a). Winners have to be concerned about creating and capturing the potential rents from their competence and/or avoid being outcompeted by other actors. Hence, exit and stagnation among the losers are a positive contribution to growth (see Eliasson and Taymaz 2000, and Eliasson, Johansson and Taymaz 2001).

Only when winners are (1) efficiently selected and (2) inclined to invest and grow and (3) the system allocates resources to finance their investments will growth occur. This is a matter of the nature of institutions (a) supporting incentives (for winners) to invest and grow and to (b) enforcing competition (Eliasson 1998a, 2001b).

\section{Industrial Dynamics}

The confrontation between technological possibilities and the market opportunities follow the creative destruction process of Table 1. Radically new innovations are normally carried by new entrants (item 1 in Table 1) together representing (in each market, competence bloc) an unsorted supply of losers and winners. The spread in business potential is, therefore, much larger than among incumbents. Some winners, therefore, subject incumbents to competitive pressure (they enter from the left in the Salter curve in Figure 1), the more so the more active the entrepreneurial entry process, and force them to reorganize or contract or leave. This process defines the industrial dynamics of an economy. Such dynamics can be successful or fail in moving economic growth or create a new industry. The general microeconomic story of "truly" endogenous economic growth will be told in the next section. 
It will explain the critical importance of non-linearity in a Schumpeterian growth process, notably the positive role of exits.

Here, we will tell (in the form of cases) the story of two failed and one immensely successful technology that nearly failed. They are (1) the emergence and disappearance of a Swedish computer industry (Eliasson 1998, 2001b), (2) the failed development of a business information systems product within Ericsson (Eliasson 1995, 1996, pp. 196 ff) and (3) the accidental success of Ericsson's mobile telephony business.

The first story is simple. Saab, the Swedish manufacturer of automobiles and military aircraft, was far ahead of its European competitors and not more than a year behind Control Data, Philco, GE, Remington Rand, Honeywell and IBM in the U.S. in developing a fully transistorized computer in 1958/1959. This was an accidental spillover product developed for internal use within Saab, but it was fast adopted for the market. While Saab was a superb technological leader in Europe (constituting, in effect, the core of the technological system for transistorized computers in Sweden), it lacked the supporting market competences of the competence bloc that was in place in the U.S. market.

The struggling Saab computer company (DataSaab), employing some 3000 people, was picked up by Ericsson in 1981 in its failed attempt to enter, together with some 40 other firms, the in fact non-existent market of business information systems. Again, the reason for failure was the narrow internal evaluation and project selection process in the many large companies entering that market in the early 1980s. This selection was based on technical rather than on market criteria. The competence bloc had been internalized within the company, providing a very narrow evaluation process, not exposing the projects to all the competences needed to orient the selection commercially. Thus, in spite of a promising technological base, the competence bloc failed at an early stage (Eliasson 1996, chapters V and VI).

The top-level managerial focus in Ericsson on the business information system as the future winner almost turned both Ericsson mobile telephony and the whole company into a casualty. No understanding of radio telephony existed at the top management level of Ericsson. In order to support its big venture into the business information systems market, Ericsson had acquired almost the entire Swedish computer and software industry. There was insufficient variety of actors in the competence bloc to support radiotelephony and to filter out the business information systems venture in time. Thanks to the persistence of an internal and suppressed intrapreneur within Ericsson, working at a fairly high level on the basis of a hidden defense account, and the keen interest of its main customer (the Swedish 
Telecommunications authority, now Telia), Ericsson was prepared (by accident) when mobile telephony suddenly emerged as a winning technology during the second half of the 1980s.

Variety of competence in the competence bloc to support efficient selections, and completeness of the competence bloc to move the winner to industrial scale production and distribution appear to be key to growth. When Ericsson top management finally understood that they had a winner, vertical support through the competence bloc immediately clicked in.

\section{Micro-Based Macro Analysis - Model Simulations}

Competent actors evaluate the projects created in the technological (innovation) system and attempt to efficiently eliminate losers without losing the winners. The rate at which winners are moved up through the competence bloc and are willing to invest and grow depends on the incentive and competition determining institutions of the economy. This growth dynamics is quantitatively demonstrated in two simulation studies on the MOSES economy (Eliasson and Taymaz 2000), Eliasson, Johanson and Taymaz 2001) which is a model approximation of the theory of EOE. These simulations illustrate the critical importance and large magnitudes of non-linear systems effects in a dynamic economy (the positive sum game). They also demonstrate how the same positive systems effects of innovative new technologies can be more or less completely eliminated if institutions are not supportive, and how the generation of long-term positive or negative macroeconomic effects from minor accidental occurrences (like policy making) are completely beyond the understanding and control of policy makers. We show that if the exit process and mobility in the labor market is not supported and encouraged by appropriate institutions in the market, the positive macroeconomic effects of new innovative entry may be completely eliminated. The large negative macroeconomic effects of containing the exit process and locking in resources, notably labor, through industrial subsidies were clearly and quantitatively demonstrated by simulation on the MOSES model economy already in the 1980s (Carlsson, Bergholm, Lindberg 1981, Carlsson 1983a, b).

As mentioned already, the productivity distribution over firms in Figure 1 gives a snapshot of the structure and dynamics of the MOSES model at a point in time. Firms along the whole curve are threatened by their "superiors" or by new entrants. If this were all, and if superior firms never made mistakes, the Moses model would eventually suffer the Schumpeter (1942) syndrome, one superior firm eventually dominating its market. All other 
firms would be forced to exit. This is exactly what happens in simulations without entry on the MOSES model (Eliasson 1983, 1984). Dynamics does not disappear, but the model economy crashes. But if innovative entry is allowed (Eliasson 1991b, Eliasson and Taymaz 2000), all incumbent firms will be threatened, and the more inferior they are compared to top of the line entrants, the larger the incentives for innovative entry. Empirical evidence indicates that entrants on the average perform less well than the average of incumbents, but the spread is much larger. Over time, hence, the radically superior technologies are introduced into an economy through new entry (Eliasson 1991b, Eliasson and Taymaz 2000). Incumbent firms are forced to respond through reorganization and/ or rationalization. Pure rationalization is usually the last step taken before death or exit. This defines the Schumpeterian creative destruction process of Table 1 which is composed of four categories of competitive action of firms, each involving an instance of investment or disinvestment.

Eliasson and Taymaz (2000) demonstrate that if there are no or only small positive effects of raising labor mobility or the exit rate, everything else the same, only disorderly market activities follow, frequently lowering long-term output growth. However, if entry is raised through appropriate institutional arrangements, but labor market mobility remains low and/or exits are slow, the positive long-term growth effects of entry are eliminated. Resources are locked in and factor prices raised, making growth investments less profitable across the economy. This is a typical non-linearity in the economy instituted through the institutions supporting the competence bloc. These results are further elaborated in Eliasson, Johansson and Taymaz (2001) who show that an overly speedy firm turnover process can disturb the market information system, causing unreliable price signaling, leading to more frequent business (selection) failure and less growth. We have again a typically non-linear relationship between innovative supply and macroeconomic growth. There is a positive relationship that turns negative when firm turnover exceeds certain levels, and, notably, is not supported by a concomitant and efficient exit process. 


\section{Bibliography}

Aghion, Philippe - Peter Howitt, 1998, Endogeous Growth Theory. Cambridge Mass, London: The MIT press.

Antonow, M. - G. Trofinov 1993. Learning through Short-Run Macroeconomic Forecasts in a Micro-to-Macro Model, Journal of Economic Behavior and Organization, 21 (2), June.

Arrow, Kenneth J., 1962. "Economic Welfare and the Allocation of Resources for Invention"; in R. Nelson (ed.), 1962, The rate and Direction of Inventive Activity: Economic and Social Factors. Princeton: Princeton University Press, 609-626.

Ballot, Gérard and Erol Taymaz, 1998. Human Capital, Technological Lock-in and Evolutionary Dynamics; in G. Eliasson and Ch. Green (eds.), 1998, The Microeconomic Foundations of Economic Growth, The University of Michigan Press, Ann Arbor, 1998. Stockholm: City University Press.

Buigues, Pierre - Alexi Jacquemin - Jean-Francois Marchipoints, 2000. Competitiveness and the Value of Intangible Assets, Edvard Elgar, UK and USA.

Burenstam-Linder, Staffan, 1961. An Essay on Trade and Transformation. Uppsala.

Carlsson, Bo, 1983a. "Industrial Subsidies in Sweden: Macro-Economic Effects and an International Comparison," Journal of Industrial Economics, XXXII (1) (Sept.), 9-14.

Carlsson, Bo, 1983b. "Industrial Subsidies in Sweden: Simulations on a Micro-to-Macro Model;" in Microeconometrics, IUI Yearbook 1982-1983. Stockholm: IUI. (ed.), 1989. Industrial Dynamics - Technological Organizational, and Structural Changes in Industries and Firms. Boston/Dordrecht/London: Kluwer Academic Publishers.

------, (ed.), 1995. Technological Systems and Economic Performance: The Case of Factory Automation. Boston/Dordrecht/London: Kluwer Academic Publishers.

-------, (ed.), 1997. Technological Systems and Industrial Dynamics. Boston/Dordrecht/ London: Kluwer Academic Publishers.

-------, (ed.), 2001. New Technological Systems in the Bio Industries - An International Study. Boston/Dordrecht/ London: Kluwer Academic Publishers (forthcoming).

Carlsson, Bo, F. Bergholm, T. Lindberg, 1981. Industristödspolitiken och dess inverkan på samhällsekonomin (Industry Subsidy Policy and its Macroeconomic Impact). Stockholm: IUI.

Carlsson, Bo and Rolf G. H. Henriksson (eds), 1991. Development Blocks and Industrial Transformation. The Dahménian Approach to Economic Development. Stockholm: IUI.

Carlsson, Bo and Rikard Stankiewicz, 1991. On the Nature, Function, and Composition of Technological Systems, Journal of Evolutionary Economics, 1 (2), 93-118

Coase, R.H., 1937. The Nature of the Firm. Economica, IV (13-16) (Nov.), 386-405.

Cohen, W.M. and D.A. Levinthal, 1990. "Absorptive Capacity: A New Perspective on Learning and Innovation." Administrative Science Quarterly, 35, 128-152.

Dahmén, E., 1950. Svensk industriell företagarverksamhet (Entepreneurial Activity in Swedish Industry, 1919-39). Stockholm: IUI. Also published in 1970 by the American Economic 
Association Translation Series under the title "Entrepreneurial Activity and the Development of Swedish Industry, 1919-1939”. Band 1 and 2. Stockholm: IUI.

Day, Richard H. and G. Eliasson (eds), 1986. The Dynamics of Market Economies, Stockholm: IUI and Amsterdam: Elsevier Science Publishers and Amsterdam: North Holland.

Day, Richard H., Gunnar Eliasson and Clas Wihlborg (eds), 1993. The Markets for Innovation, Ownership and Control. Stockholm: IUI and Amsterdam: North-Holland.

Eliasson, Gunnar, 1976. "Business Economic Planning; Theory, Practice and Comparison”. Stockholm: Swedish Industrial Publications, and London-New York-Sydney- Toronto: John Wiley \& Sons.

-, 1977. "Competition and Market Processes in a Simulation Model of the Swedish Economy", American Economic Review, 67 (1), 277-281.

-------, 1980. "Elektronik, teknisk förändring och ekonomisk utveckling”, Datateknik, ekonomisk tillväxt och sysselsättning (DEK), Stockholm.

-------, 1983. On the Optimal Rate of Structural Adjustment; in Eliasson, Sharefkin and Ysander (eds.), 1986).

-------, 1984a. Micro Heterogeneity of Firms and Stability of Growth, Journal of Behavior and Economic Organization, 5 (3-4), (Sept.-Dec.)249-298 (also in R.H. Day, and G. Eliasson, eds, 1986).

1985. The Firm and Financial Markets in the Swedish Micro-to-Macro Model - Theory, Model and Verification. Stockholm: IUI.

, 1986. Kunskap, information och tjänster - en studie av svenska industriföretag (Knowledge, Information and Service Production - a study of Swedish manufacturing firms). Stockholm: IUI.

-------, 1987. Technological Competition and Trade in the Experimentally Organized Economy, Research Report No. 32. Stockholm: IUI.

, 1989. The Dynamics of Supply and Economic Growth - how industrial knowledge accumulation drives a path-dependent economic process; in Bo Carlsson (ed.), 1989.

-------, 1990a. The Firm as a Competent Team, Journal of Economic Behavior and Organization, 13 (3), 275-298.

-------, 1990b. "The Knowledge-Based Information Economy”; Chapter I i G. Eliasson, S.Fölster et al., 1990, The Knowledge Based Information Economy. Stockholm: IUI.

--------, 1991a. Modeling the Experimentally Organized Economy, Journal of Economic Behavior and Organization, 16 (1-2), 153-182.

, 1991b. Deregulation, Innovative Entry and Structural Diversity as a Source of Stable and Rapid Economic Growth, Journal of Evolutionary Economics, (1), 49-63.

-------, 1992. "Business Competence, Organizational Learning, and Economic Growth: Establishing the Smith-Schumpeter-Wicksell (SSW) Connection"; in F.M. Scherer and M. Perlman (eds), Entrepreneurship, Technological Innovation, and Economic Growth. Studies in the Schumpeterian Tradition. Ann Arbor: The University of Michigan Press, 1992.

, 1995. Teknologigenerator eller nationellt prestigeprojekt? Exemplet svensk flygindustri (A Technology Generator or a National Prestige Project? The Swedish Aircraft Industry). Stockholm: City University Press. 
1996. Firm Objectives, Controls and Organization - the use of information and the transfer of knowledge within the firm. Boston/Dordrecht/London: Kluwer Academic Publishers.

, 1997a. General Purpose Technologies, Industrial Competence Blocs and Economic Growth; in B. Carlsson, ed. (1997).

-1997b. The Venture Capitalist as a Competent Outsider; mimeo, INDEK, KTH, IEO R: 1997-06. Stockholm.

, 1998a. Svensk datorindustri - en kompetensblocksanalys av dess framväxt och försvinnande (Swedish Computer Industry - a competence bloc analysis of its emergence and disappearance); in P. Heum (ed.), Kompetense og Verdiskapning. SNFs Årsbok 1998. Bergen: Fagboksforlaget. An English version exists: Eliasson (2001b).

, 1998b. Information Efficiency, Production Organization and Systems Productivity Quantifying the Systems Effects of EDI Investments. INDEK, KTH, TRITA-IEO R 1996:6; in Macdonald - Madden - Salama (eds), 1998, Telecommunications and Social Economic Development. Amsterdam: North Holland.

, 1998c. "Competence Blocs and Industrial Policy in the Knowledge Based Economy". OECD Science, Technology, Industrial (STI) Revue, 1998.

-------, 1999. "Communication, Information, Technology and Firm Performance"; in MacDonald - Nightingale (1999).

-------, 2000a. Industrial Policy, Competence Blocs and the Role of Science in the Economic Development. KTH, TRITA.IEO R 1998-08. To be published in Journal of Evolutionary Economics, No. 1, 2000.

-, 2000b. The Industrial Potential of Biotechnology - a competence bloc analysis; i de la Mothe - Niosi; eds. (2000).

-, 2000c. Making Intangibles Visible - the value, the efficiency and the economic consequences of knowledge; in Buigues - Jacquemin - Marchipon (2000).

-------, 2000d. The Anatomy of a Production Plant, mimeo, KTH, Indek.

-------, 2001a. The Role of Knowledge in Economic Growth. KTH-TRITA, Stockholm. To be published in Helliwell, John (ed.), 2001.

-------, 2001b. The Emergence and the Disappearance of a Swedish Computer Industry - a competence bloc analysis of the chance factor KTH, TRITA series, Stockholm.

-------, 2001c. The Health care competence bloc; in Carlsson, Bo, ed. (2001).

Eliasson, Asa, 2001. A Competence Bloc Analysis of the Economic Potential of Biotechnology in Agriculture and Food Production; in Carlsson, B. (ed.) (2001).

Eliasson, Gunnar and Charlotte Eliasson, 1996. The Computer \& Communications Industry A Chronicle of Events that Mark the Experimental Evolution of a New Information Industry; in G. Eliasson (1996).

Eliasson, Gunnar and Åsa Eliasson, 1996. The Biotechnological Competence Bloc, Revue d'Economie Industrielle, $78-4^{0}$, Trimestre.

-------, 2000. "The Market for Strategic Acquisitions", mimeo, KTH, Stockholm.

Eliasson, G., H, Fries, L. Jagrénm and L. Oxelheim, 1984. Hur styrs storföretag? Stockholm: IUI. 
Eliasson, Gunnar and Dan Johansson, 1999. Dynamik och flexibilitet $i$ svensk IT-industry (Dynamics and Flexibility in Swedish IT-industry). Stockholm: City University Press.

Eliasson, Gunnar, Dan Johansson and Erol Taymaz, 2000. Firm Turnover and the Rate of Growth, mimeo, INDEK, KTH, Stockholm.

Eliasson, Gunnar and Erol Taymaz, 2000. Institutions, Entrepreneurship, Economic Flexibility and Growth - experiments on an evolutionary model. KTH, INDEK, TRITA-IEO-R 1999:13; to be published in Cantner-Hanush-Klepper, 1999, Economic Evolution, Learning and Complexity - Econometric, Experimental and Simulation Approaches.

Helliwell, John (ed.), 2001, The Contribution of Human and Social Capital to Sustained Economic Growth and Well-being, HRDC. Canada.

Hicks, J.R., 1939. Value and Capital (second ed.). Oxford: Clarendon Press, 1946.

Knight, F., 1921. Risk, Uncertainty and Profit. Boston: Houghton-Mifflin.

Laestadius, Staffan, 1999. Marshallian Dynbamics and New Growth Theory, KTH, TRITA IEO R 1999:1, Stockholm.

Loasby, B.J., 1991. Alfred Marshall's Connecting Principles of Firms and Markets. Paper presented to the RES Annual Conference, University of Warwick, 8 April 1991.

Lucas, R.E., Jr, 1988. On the Mechanics of Economic Development, Journal of Monetary Economics, 22, 1, 3-41.

Marshall, Alfred, 1890. Principles of Economics. London. 1919, Industry and Trade. London.

Macdonald, Stuart and John Nightingale, 1999. Information and Organization, North Holland.

Menger, Carl, 1871. Grundsätze der Volkswirtschaftslehre, Vienna.

Mises, Ludwig, 1949. Human Action, Contemporary Books. Chicago

de la Mothe, John and Jorge Niosi (eds), 2000, The Economic and Social Dynamics of Biotechnology. Boston/Dordrecht/London; Kluwer Academic Publishers

Nadiri, Ishaq, 1978. A Dynamic Model of Research and Development Expenditure; in B. Carlsson, G. Eliasson and I. Nadiri (eds.), 1978, The Importance of Technology and the Permanence of Structure in Industrial Growth, IUI Conference Reports, 1978:2, Stockholm.

-------, 1993. Innovations and Technological Spillovers, NBER Working Paper No. 4423. Cambridge, MA.

Romer, P.M., 1986. Increasing Returns and Long-Run Growth, Journal of Political Economy, 94 (5), Oct., 1002-1037.

-------, 1987. "Growth based on Increasing Returns due to Specification”, AER, papers and proceedings (May).

-------, 1990. Endogenous Technological Change, Journal of Political Economy, Vol. 98, No. 5 pt. 2, pp. 71-102.

Salter, W.E.G., 1960. Productivity and Technical Change, MA: Cambridge University Press.

Schumpeter, Joseph, 1911 (English edition 1934), The Theory of Economic Development. Harvard Economic Studies. Vol. XLVI. Harvard University Press. Cambridge, MA.

-------, 1942, Capitalism, Socialism and Democracy. New York: Harper \& Row. 
Smith, Adam, 1776. An Inquiry into the Nature and Causes of the Wealth of Nations. New York: Modern Library, 1937.

Sraffa, P., 1926. "The Laws of Return under Competence Conditions", The Economic Journal, Vol. XXXVI (Dec.), pp. 535-550.

Stankiewicz, Rikard, 2001. The Cognitive Dynamics of Biotechnology and the Evolution of Its Technological Systems, ch. 3 in Carlsson (ed.), forthcoming.

Walras, L., 1874, Elements d'économie politique pure. English translation of 1926 edition: Elements of Pure Economics, or the Theory of Social Wealth. London: Allen and Unwin, 1954.

Winter, S.G., 1964. "Economic 'Natural Selection' and the Theory of the Firm," Yale Economic Essays, 4 (1) (Spring), 225-272.

-------, 1986. "Schumpeterian Competition in Alternative Technological Regimes," Chapter 8 in R. Day, and G. Eliasson, eds. (1986).

Young, Allyn A., 1928. Increasing Returns and Economic Progress, Economic Journal, XXXVIII, 152, 527-542. 
Table 1. The four mechanisms of Schumpeterian creative destruction and economic growth

1. Innovative entry

enforces (through competition)

2. Reorganization

3. Rationalization

or

4. Exit (shut down)

Source: "Företagens, institutionernas och marknadernas roll i Sverige", Appendix 6 in A. Lindbeck (ed.), Nya villkor för ekonomi och politik (SOU 1993:16) and G. Eliasson (1996a, p. 45).

Table 2A. The dominant selection problem

Error Type I: Losers kept too long

Error Type II: Winners rejected

Source: G. Eliasson - Å. Eliasson, 1996. The Biotechnological Competence Bloc, Revue d'Economie Industrielle, $78-4^{0}$, Trimestre.

\section{Table 2B. Actors in the competence bloc}

1. Competent and active customers

2. Innovators who integrate technologies in new ways

3. Entrepreneurs who identify profitable innovations

4. Competent venture capitalists who recognize and finance the entrepreneurs

5. Exit markets that facilitate ownership change

6. Industrialists who take successful innovations to industrial scale production

Source: G. Eliasson - Å. Eliasson, 1996. The Biotechnological Competence Bloc, Revue d'Economie Industrielle, $78-4^{0}$, Trimestre. 
Figure 1. Labor productivity distributions (Salter curves) in Swedish Manufacturing 1983 and 1990

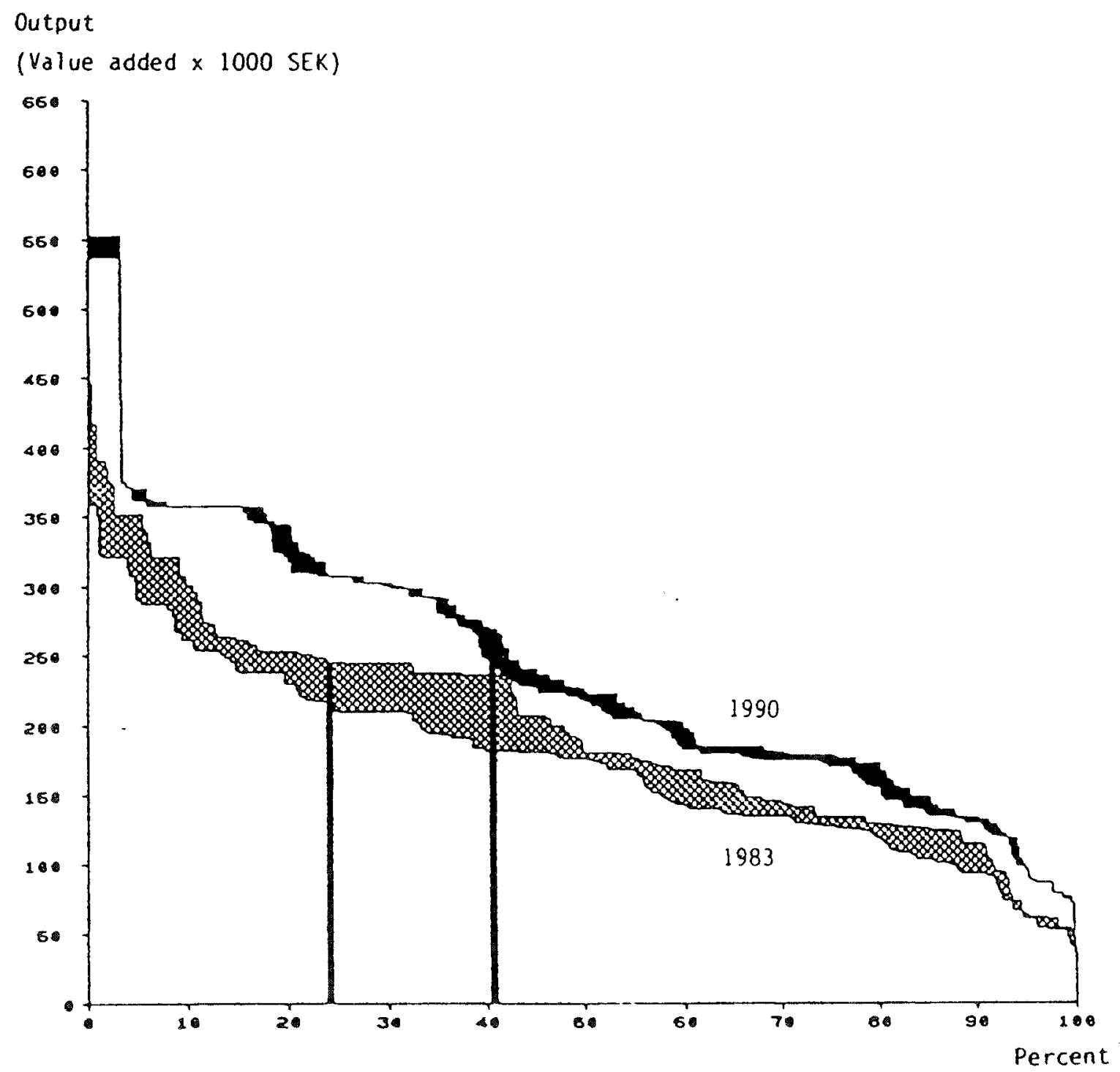

